\title{
PENGARUH IDEOLOGI GENDER TERHADAP PERKEMBANGAN HAK WARIS PEREMPUAN BALI
}

\author{
Oleh: \\ I Ketut Sudantra', I Gusti Ngurah Dharma Laksana²
}

\begin{abstract}
This article aiming to review the change of gender ideology that happened on the society and its influence on development of Balinese customary law, especially that concerning women's inheritance. The review based on result of literary research with conceptual, historical, and futuristic legal approach. The review result concluded that there is already a change on gender ideology of society. The change of gender ideology on Balinese customary society, especially that happened on intellectuals and custom 's important figures, had causing the birth of Majelis Utama Desa Pakraman (MUDP) Third Pasamuan Agung of 2010 Decree that lifted Balinese women's dignity on inheritance, which decreed that women in certain limit have right on their parent's inheritance.
\end{abstract}

Keywords: gender indeology, Balinese customary law, women's inheritance right

\begin{abstract}
Abstrak
Tulisan ini bertujuan untuk mengkaji perubahan ideologi gender yang terjadi dalam masyarakat dan pengaruhnya terhadap perkembangan hukum adat Bali, terutama yang menyangkut hak waris perempuan. Kajian didasarkan pada hasil penelitian kepustakaan (doktriner) dengan pendekatan konseptual, historis dan futuristik hukum. Hasil kajian menyimpulkan bahwa telah terjadi perubahan ideologi gender dalam masyarakat. Perubahan ideologi gender dalam masyarakat adat Bali, terutama yang terjadi dikalangan intelektual dan tokoh-tokoh adat, menyebabkan lahirnya Keputusan Pasamuan Agung III Majelis Utama Desa Pakraman (MUDP) Bali Tahun 2010 yang mengangkat derajat dan harkat perempuan Bali di bidang pewarisan, di mana diputuskan bahwa perempuan dalam batas-batas tertentu berhak atas harta peninggalan orang tuanya
\end{abstract}

Kata kunci: ideologi gender, hukum adat Bali, hak waris perempuan.

1 Penulis pertama adalah Dosen Fakultas Hukum Universitas Udayana, Denpasar, Bali; pengajar mata kuliah Gender dalam Hukum dan mata kuliah Hukum Adat Bali. Email: ketut_sudantra@unud.ac.id

2 Penulis kedua adalah Dosen Fakultas Hukum Universitas Udayana, Denpasar; pengajar mata kuliah Gender dalam Hukum. Email:ngurahdharmalaksana@yahoo.com 


\section{PENDAHULUAN}

Pembicaraan mengenai masalahmasalah gender (baca: jénder) sudah dimulai sejak lebih dari tiga dasawarsa yang lalu, yaitu ketika pada tahun 1978 Presiden Soeharto membentuk Kantor Menteri Muda Urusan Peranan Wanita yang mengurus kebijakankebijakan publik yang secara eksplisit bertujuan menangani masalahmasalah perempuan, kemudian lebih intens lagi sejak tahun 2000 ketika Presiden RI waktu itu, Abdrurrahman Wahid, mengeluarkan instruksi yang ditujukan kepada jajaran pemerintahan (Menteri, Kepala Pemerintahan Non Departemen, Pimpinan Kesekretariatan Lembaga Tertinggi/ Tinggi Negara, Panglima TNI, Kapolri, Jaksa Agung RI, Gubernur, Bupati/Walikota) untuk melaksanakan pengarusutamaan gender guna terselenggaranya perencanaan, penyusunan, pelaksanaan, pemantauan, dan evaluasi atas kebijakan dan program pembangunan nasional yang berspektif gender sesuai dengan bidang tugas dan fungsi, serta kewenangan masing-masing. Dasar pertimbangan dikeluarkannya Instruksi bertanggal tanggal 19 Desember 2000 itu adalah untuk meningkatkan kedudukan, peran, dan kualitas perempuan, serta upaya mewujudkan kesetaraan dan keadilan gender dalam kehidupan berkeluarga, bermasyarakat, berbangsa dan bernegara, maka pemerintah memandang perlu melakukan strategi pengarusutamaan gender ke dalam seluruh proses pembangunan nasional $^{3}$.

Sejak itu, berbagai program dan kegiatan pembangunan berperspektif gender gencar dilakukan sehingga mempengaruhi nilai-nilai, normanorma dan anggapan-anggapan tentang relasi laki-laki dan perempuan. Segala nilai, norma, anggapan-anggapan serta pelabelan yang berkaitan dengan relasi antara perempuan dan laki-laki inilah yang disebut ideologi gender. Dengan kalimat lain, ideologi gender adalah seperangkat ide-ide dan sistem nilai yang melegitimasi persifatan, peran dan status laki-laki dan perempuan. Pembentukan ideologi gender ini didahului pembentukan identitas feminin dan maskulin yang menjadi struktur dan sifat manusia, di mana ciri-ciri dasar dan sifat itu dibentuk sejak masa kanak-kanak awal. Ideologi gender ini dapat terbentuk di berbagai tingkat, mulai dari tingkat negara, komunitas, sampai tingkat keluarga dan tersosialisasikan melalui pelbagai pranata sosial yang dikendalikan oleh penguasa-penguasa pelbagai tingkatan $\mathrm{itu}^{4}$.

Karakter ideologi gender sebagaimana halnya karakter ideologiumumnya konservatif dan selalu

3 Lihat konsideran menimbang dari Instruksi Presiden Nomor 9 Tahun 2000 tentang Pengarusutamaan Gender dalam Pembangunan Nasional, dalam: Kelompok Kerja Convention Watch Pusat Kajian Wanita dan Gender Universitas Indonesia, 2004, Hak Azasi Perempuan, Instrumen Hukum untuk Mewujudkan Keadilan Gender, Yayasan Obor, Jakarta, hlm.156.

4 Agnes Widanti, 2005, Hukum Berkeadilan Gender, Penerbit Buku Kompas, hlm. 32. 
ketinggalan di belakang perubahan ${ }^{5}$, namun harus diakui bahwa tidak ada satu pun hal di dunia ini yang dapat terbebas dari hukum perubahan, tidak terkecuali ideologi gender. Sesungguhnya perubahan yang terjadi serba mencakup, meliputi seluruh aspek kehidupan dalam masyarakat, hanya saja intensitas atau tingkat perubahannya yang berbeda-beda ${ }^{6}$. Oleh karena itu, suatu keniscayaan pula bahwa ideologi gender pun dapat berubah mengikuti dan atau bersamaan dengan perubahan masyarakat pengemban nya. Masyarakatlah yang mengkonstruksi persifatan, peran dan status laki-laki dan perempuan sehingga perubahan yang terjadi dalam masyarakat akan memengaruhi nilai-nilai, sikap ataupun perilaku masyarakat yang bersangkutan dalam memersepsikan relasi laki-laki dan perempuan dalam keluarga maupun masyarakat.

Ideologi gender mempunyai pengaruh yang sangat besar terhadap berbagai bidang kehidupan, sehingga sangat penting untuk dikaji. Sebelumnya, memang telah ditemukan beberapa kajian yang membahas ideologi gender dari beberapa perspektif. Misalnya, Siti Cholisotul Hamidah mengkaji representasi ideologi gender dalam buku teks Bahasa Indonesia ${ }^{7}$; Inayah

$5 \quad$ Ibid.

6 Robert H. Lauer, 2001, Perspektif tentang Perubahan Sosial, terjemahan Alimandan, PT Rineka Cipta, Jakarta, hlm. 4.

7 Siti Cholisotul Hamidah, 2014, "Representasi Ideologi Gender dalam buku Teks Bahasa
Rohmaniyah dalam tulisannya menunjukkan pengaruh timbal-balik antara ideologi gender dan agama ${ }^{8}$; dan lain-lain. Meskipun demikian, kajian yang berkaitan dengan ideologi gender masih tetap penting dan relevan untuk dibahas, terutama dalam hubungannya dengan perkembangan hukum. .

Kajian ini berupaya untuk melihat perubahan ideologi gender dalam masyarakat dan pengaruhnya terhadap perkembangan hukum adat Bali, terutama yang menyangkut hak waris perempuan. Pertanyaan yang ingin dijawab adalah: (1) apakah telah terjadi perubahan ideologi gender dalam masyarakat adat Bali?; (2) bagaimana pula pengaruh perubahan ideologi gender tersebut terhadap perkembangan hak perempuan Bali dalam mewaris?

\section{METODE PENELITIAN}

Penulisan ini berdasarkan hasil penelitian kepustakaan, yang mencoba mengkaji pengaruh ideologi gender terrhadap perkembangan hak waris perempuan Bali, terutama setelah dikeluarkannya Keputusan Majelis Utama Desa Pakraman (MDP) Bali Nomor: 01/Kep/Psm-3/MDP Bali/ $\mathrm{X} / 2010$ tentang Hasil-hasil Pasamuhan Agung III MDP Bali, tertanggal 15 Oktober 2010. Apabila dilihat dari

Indonesia", tersedia di http://karya-ilmiah. um.ac.ad/index.php/disertasi/article/ view/37015, diakses: 22 Januari 2017.

8 Inayah Rohmaniyah, 2009, "Gender dan Konstruksi Perempuan dalam Agama", Jurnal Studi Ilmu-ilmu Al Quran dan Hadis, Vol 10 No 2, Juli 2009, hlm. 217 
tipologi penelitian hukum, tulisan ini termasuk kajian yang didasarkan pada hasil penelitian doktriner atau penelitian hukum normatif dalam tataran penelitian terhadap asasasas hukum ${ }^{9}$. Beberapa pendekatan yang digunakan adalah pendekatan konseptual untuk menjelaskan konsepkonsep gender dan hukum adat Bali yang relevan; pendekatan historis untuk menunjukkan perkembangan hak waris perempuan Bali; serta pendekatan futuristik hukum untuk memprediksi perkembangan hukum adat Bali di masa datang terkait hak perempuan.

Kajian ini mengandalkan dukungan data sekunder, baik yang berupa peraturan ataupun dokumen lainnya serta literatur-literatur yang relevan. Analisis dilakukan secara kualitatif dan hasilnya disajikan secara deskriptif-analitis.

\section{HASIL DAN PEMBAHASAN}

3.1. Perubahan Ideologi Gender dalam Masyarakat

Gender adalah konsep yang membedakan antara laki-laki dan perempuan berdasarkan sifat-sifat, status, ataupun peran yang melekat padanya. Persifatan, pelabelan, pemberian status dan peran lakilaki dan perempuan tersebut dikonstruksi secara sosial maupun kultural. Misalnya, sudah menjadi pandangan umum dalam masyarakat

9 Bambang Sunggono, 2003, Metodologi Penelitian Hukum, PT RajaGrafindo Persada, Jakarta, hlm. 42-43. bahwa manusia dengan jenis kelamin perempuan di klaim sebagai sosok yang lemah dan emosional, sementara laki-laki dianggap kuat dan rasional. Pelabelan itu didasarkan kepada fakta yang ditemui berdasarkan pengalamanpengalaman di lingkungan sosialnya sehingga kemudian dianggap sebagai kodrat. Sifat-sifat itu sesungguhnya bukanlah kodrat yang mutlak melekat pada masing-masing jenis kelamin tersebut, sebab ciri-ciri dari sifat itu sendiri merupakan sifat-sifat yang dapat saja dipertukarkan, tergantung kepada karakter manusianya yang terbentuk oleh kondisi lingkungan dan sosialnya. Seorang perempuan yang sejak bayi tumbuh, hidup dan terlatih dalam lingkungan sosial yang keras, dapat saja mempunyai sifat-sifat yang keras, tegas dan mandiri, bahkan mungkin pula mempunyai ciri-ciri fisik sebagaimana umumnya laki-laki: kuat dan berotot. Sebaliknya, tidak tertutup kemungkinan adanya seorang laki-laki yang terbiasa hidup dalam keluarga yang penuh dengan segala kemudahan dan manja kemudian akan tumbuh menjadi sosok manusia dengan fisik yang lemah dan sifat-sifat yang manja.

Kondisi biologis, ciri-ciri fisik serta sifat yang berbeda antara laki-laki dan perempuan kemudian memengaruhi nilai-nilai yang hidup dalam masyarakat tentang peran dan status yang dianggap ideal bagi masing-masing jenis kelamin tersebut. Misalnya, karena perempuan cenderung 
mempunyai kondisi fisik yang lemah sebagai akibat dari kodratnya yang mengalami menstruasi, mengandung, melahirkan, dan menyusui, kemudian dinilai lebih tepat diberi peran dalam urusan-urusan domestik, seperti memasak untuk keluarga, mengasuh dan memelihara anak, bersih-bersih rumah, dan sebagainya yang dianggap sebagai pekerjaan-pekerjaan yang tidak beresikodantidakterlalumembutuhkan kekuatan fisik. Sebaliknya, kaum lakilaki yang kuat dinilai lebih tepat diberi peran untuk mencari nafkah di luar rumah yang penuh dengan tantangan. Dalam kehidupan berumah tangga, istri kemudian diberi status sebagai ibu rumah tangga, sedangkan suami sebagai kepala keluarga. Perbedaanperbedaan pensifatan, peran ataupun status antara laki-laki dan perempuan yang dibentuk oleh masyarakat inilah yang disebut sebagai perbedaan gender (gender differences).

Jadi, berbeda dengan konsep seks yang statis, gender adalah sesuatu konsep yang dinamis. Karena gender dikonstruksi oleh masyarakat berdasarkan nilai-nilai yang dianut nya, maka konsep gender dapat saja berubah mengikuti nilai-nilai yang tumbuh, hidup, dan berkembang dalam masyarakatnya. Konsep gender dapat berubah dari waktu ke waktu, sehingga perbedaan peran dan status laki-laki dan perempuan dapat berbeda dari waktu ke waktu. Paling mudah menjelaskan perubahan nilai-nilai gender dalam masyarakat dilihat dari dimensi waktu dengan mengambil contoh pada perubahan mode laki-laki dan perempuan, karena mode adalah suatu konsep gender yang paling dinamis. Pada satu waktu di masa lalu, mungkin laki-laki dan perempuan dengan cepat dan mudah dapat dibedakan dari jauh dengan melihat pakaian yang dikenakannya: perempuan memakai rok sedangkan laki-laki memakai celana panjang.

Di masa sekarang, hal itu sudah sulit dilakukan karena lakilaki dan perempuan semuanya sudah lazim bercelana panjang. Sekarang ini, untuk memastikan apakah sosok bercelana panjang yang dilihat dari jauh, laki-laki atau perempuan, masih harus diperhatikan dengan cermat tidak hanya dilihat dari busana yang dikenakannya.

Konsep gender juga dapat berbeda secara lintas budaya, sehingga peran dan status laki-laki dan perempuan yang dianggap ideal dalam masyarakat tertentu belum tentu dapat diterima sebagai perbedaan peran dan status yang ideal pula pada masyarakat lainnya. Pemahaman inilah yang dapat menjelaskan bagaimana laki-laki dan perempuan di dalam masyarakat Bali mempunyai kedudukan yang berbeda dengan status laki-laki dan perempuan dalam keluarga Jawa atau Minangkabau. Di Bali, keturunan dilanjutkan melalui garis laki-laki (patrilineal, purusa); sebaliknya di Minangkabau keturunan dilanjutkan melalui garis perempuan; sedangkan 
dalam masyarakat Jawa keturunan dilanjutkan baik dari garis laki-laki maupun perempuan.

Cara menarik garis keturunan ini kemudian berimplikasi kepada pemberian status kepada anak lakilaki dan perempuan dalam persoalan waris, di mana dalam masyarakat adat Bali hanya anak laki-laki yang diberi status sebagai ahli waris karena dianggap bertanggungjawab melanjutkan tanggungjawab keluarga baik lahir maupun batin (sekalaniskala); sedangkan anak perempuan diposisikan bukan sebagai ahli waris atau hanya diberi status sebagai ahli waris terbatas dan bersyarat, yaitu hanya berhak menikmati harta warisan orang tua sepanjang yang bersangkutan masih tinggal dan menunaikan kewajiban-kewajiban di lingkungan keluarga ayahnya ${ }^{10}$

Dari uraian mengenai konsep gender di atas, maka dapatlah dikemukakan bahwa perbedaan antara laki-laki dan perempuan yang merupakan kodrat Tuhan, kemudian dapat menimbulkan perbedaan gender, suatu perbedaan yang menyangkut pembedaan peran, status dan tanggungjawab masing-masing dalam keluarga maupun masyarakat. Contoh yang paling sederhana mengenai perbedaan gender tersebut adalah pembagian kerja secara seksual dalam keluarga, seperti pekerjaan mengurus

10 Wayan P Windia dan I Ketut Sudantra, 2006, Pengantar Hukum Adat Bali, Lembaga Dokumentasi dan Publikasi Fakultas Hukum Universitas Udayana, hlm. 78, 81, 118. rumah yang umumnya diberikan kepada perempuan dan peran mencari nafkah diberi kepada laki-laki. Dalam ranah hukum, pembedaan nilainilai antara laki-laki dan perempuan dinormakan dalam pembedaan status hukum, misalnya perempuan yang sudah kawin (istri) diberi status sebagai ibu rumah tangga sedangkan laki-laki menikah (suami) diberi status sebagai kepala keluarga ${ }^{11}$; dalam masyarakat tertentu anak laki-laki diberi status sebagai ahli waris, sedangkan anak perempuan tidak.

Pertanyaannya adalah apakah perbedaan-perbedaan gender yang sudah dan kini sedang berlangsung dalam masyarakat tersebut merupakan suatu masalah sehingga harus diubah? Pertanyaan ini bukan pertanyaan yang gampang untuk dijawab secara memuaskan, karena hal ini menyangkut suatu ideologi atau nilainilai yang dianut dalam masyarakat. Sejauh nilai-nilai yang hidup dalam masyarakat memandang perbedaan gender tersebut sebagai sesuatu hal yang wajar dan tidak menimbulkan kerugian bagi salah satu jenis kelamin, mungkin perbedaan-perbedaan gender tersebut bukanlah suatu masalah sehingga tidak ada urgensi nya untuk diubah. Ketika nilai-nilai yang hidup dalam masyarakat mulai bergeser dan menganggap bahwa dalam perbedaan gender tersebut terdapat ketidakadilan bagi salah satu jenis kelamin, maka sesungguhnya pada saat itu perbedaan

11 Lihat: Pasal 31 ayat (3) Undang-undang Nomor 1 Tahun 1974 tentang Perkawinan. 
gender itu sudah menjadi suatu masalah yang perlu dipikirkan jalan keluarnya.

Harus diakui, bahwa perubahan nilai-nilai dalam masyarakat adalah suatu keniscayaan, apalagi dalam suatu masyarakat yang terus berubah. Bersamaan dengan perubahanperubahan masyarakat, terjadi pula perubahan nilai-nilai gender, yaitu nilai-nilai yang menyangkut relasi antara laki-laki dan perempuan. Dewasa ini, sebagai akibat dari semakin kompleks nya kehidupan dalam masyarakat modern, tidak sedikit mitos menyangkut relasi lakilaki dan perempuan yang selama ini kuat memengaruhi persepsi, sikap, dan perilaku masyarakat mulai diabaikan. Misalnya, mitos yang memersepsikan bahwa laki-laki tabu melakukan "pekerjaan-pekerjaan perempuan", seperti memasak, mencuci, mengurus rumah, dan sebagainya, sudah tidak banyak lagi diindahkan; bersamaan dengan runtuhnya mitos yang memersepsikan perempuan sebagai "konco wingkinng" (teman di dapur atau teman di belakang) dari suami. Fakta menunjukkan bahwa dalam masyarakat -terutama diperkotaan dan perlahan-lahan menjalar ke perdesaanmitos-mitos yang berkaitan dengan peran laki-laki dan perempuan sudah banyak dijungkirbalikkan. Kini sudah banyak perempuan berperan dominan dalam pekerjaan nafkah dan sebaliknya tidak sedikit laki-laki yang bersedia berbagi peran dengan perempuan di rumah tangga, baik atas dasar rasa sukarela maupun "paksarela" karena tuntutan kehidupan. Semakin lama, semakin banyak orang yang terbiasa melakukan hal itu sehingga dianggap wajar oleh masyarakat. Terlibatnya perempuan dalam mencari nafkah menyebabkan adanya kontribusi perempuan di dalam pembentukan harta keluarga. Tidak sedikit perempuan yang belum kawin maupun yang sudah kawin (istri) mempunyai karier yang baik dalam pekerjaannya dan berpenghasilan cukup bagi dirinya, bahkan tidak sedikit pula yang menjadi tulang-punggung keluarga. Itu menyebabkan ketergantungan perempuan terhadap laki-laki dari segi nafkah menjadi berkurang, bahkan hilang sama sekali. Adanya kontribusi perempuan dalam pembentukan harta keluarga serta berkurangnya ketergantungan nya kepada kaum lakilaki menyebabkan posisi perempuan dalam pengambilan keputusan menjadi lebih kuat. Bersamaan dengan itu, persepsi masyarakat terhadap perempuan bekerja juga menjadi berubah. Fenomena ini adalah salah satu penanda telah bergesernya ideologi gender dalam masyarakat.

Sebagai konsekuensi dari perubahan ideologi gender tersebut, perbedaan gender yang semula mapan tanpa ada protes dari salah satu jenis kelamin, kini menjadi potensial menimbulkan gugatan dan dianggap bermasalah karena salah satu pihak mulaimerasakan adanya ketidakadilan, yaitu suatu perlakuan yang berat 
sebelah $^{12}$. Gerakan-gerakan dari aktivis perempuan yang belakangan ini gencar memperjuangkan hakhak perempuan dalam segala bidang kehidupan dapat dipandang sebagai manifestasi dari gugatan terhadap kondisi yang dialami kaum perempuan yang dirasa tidak adil.

Secara akademis, ketidakadilan yang berakar pada relasi laki-laki dan perempuan ini lazim disebut sebagai ketidakadilan gender (gender inequalites). Mansour Fakih $^{13}$ menjelaskan bahwa ketidakadilan gender termanifestasikan dalam berbagai bentuk, yakni: marginalisasi atau peminggiran salah satu jenis kelamin yang menimbulkan kemiskinan ekonomi; subordinasi yang menempatkan salah satu jenis kelamin pada posisi yang lebih rendah dari jenis kelamin lainnya dalam proses pengambilan keputusan; pembentukan stereotipe atau melalui pelabelan negatif kepada salah satu jenis kelamin; kekerasan (violence) yang berbasiskan perbedaan jenis kelamin; beban kerja lebih banyak (burden); serta sosialisasi ideologi peran gender yang merugikan salah satu jenis kelamin. Manifestasi ketidakadilan gender tersebut di atas tidak bisa dipisah-

12 Pemahaman tentang arti "ketidakadilan" sebagai "perlakuan berat sebelah" diadaptasi dari pengertian "adil" dalam bahasa Indonesia yang berarti sama berat, tidak berat sebelah atau tidak memihak. Lihat: Pusat Bahasa Departemen Pendidikan Nasional, 2001, Kamus Besar Bahasa Indonesia, Edisi Ketiga, Balai Pustaka, Jakarta.., hlm. 8.

13 Mansour Fakih, 1996, Analisis Gender \& Transformasi Sosial, Pustaka Pelajar, Yogyakarta., hlm. 13. pisahkan, karena saling berkaitan dan berhubungan, saling memengaruhi secara dialektis. Tidak ada satu pun manifestasi ketidakadilan gender yang lebih penting, lebih esensial, dari yang lain. Misalnya, marginalisasi ekonomi kaum perempuan mungkin terjadi karena stereotipe tertentu atas kaum perempuan dan itu menyumbang kepada subordinasi, kekerasan kepada kaum perempuan, yang pada akhirnya tersosialisasikan dalam keyakinan, ideologi dan visi kaum perempuan sendiri. Sebaliknya, dapat saja terjadi bahwa sosialisasi ideologi gender justru menjadi sumber dari bentukbentuk ketidakadilan lainnya. Dengan demikian, tidaklah dapat dinyatakan bahwa marginalisasi kaum perempuan adalah menentukan dan terpenting dari yang lain dan oleh karena itu perlu mendapat perhatian lebih. Atau sebaliknya, bahwa sosialisasi ideologi gender adalah masalah paling mendasar yang harus dipecahkan lebih dahulu. Manifestasi ketidakadilan gender tersebut di atas, dapat terjadi dalam pelbagai tingkatan, baik di tingkat negara,tempatkerja, organisasiataupun dunia pendidikan, termasuk dalam masyarakat di berbagai kelompok etnik, bahkan dalam tingkatan rumah tangga. Dalam masyarakat adat, manifestasi ketidakadilan gender tumbuh dan berkembang dalam kultur masyarakat yang bersangkutan yang adakalanya dipengaruhi oleh tafsir keagamaan.

Berbagai bentuk ketidakadilan gender itu -yang dulu dianggap wajar 
dan diterima begitu saja- kini mulai mendapat perlawanan dari banyak kalangan, dipelopori oleh berbagai Lembaga Swadaya Masyarakat (LSM) dan aktivis-aktivis perempuan. Mereka melakukan berbagai upaya untuk mewujudkan kesetaraan dan keadilan gender melalui pendidikan, pelayanan, dan pendampingan dan lain-lain.

\subsection{Perubahan Ideologi Gender dan Perkembangan Hak Waris Perempuan Bali}

Perubahan-perubahan dalam masyarakat dapat menimbulkan perubahan hukum, begitu juga sebaliknya. Perubahan ideologi gender dalam masyarakat pada gilirannya akan berpengaruh pula terhadap perkembangan norma-norma hukumnya, sehingga norma-norma hukum yang mengatur relasi laki-laki dan perempuan juga akan mengalami perubahan. Demikian pula yang terjadi dengan hukum adat Bali sebagai hukum yang hidup (living law) dalam masyarakat (adat) Bali, tidak lepas pula dari perubahan-perubahan itu. Sesuai dengan sifat hukum adat yang dinamis dan fleksibel ${ }^{14}$, hukum adat Bali memang dapat berubah, baik yang berubah secara alami (natural) ataupun yang sengaja diubah melalui rekayasa sosial (social eingenering).

14 R. Van Dijk menyebut tiga sifat umum hukum adat, yaitu (1) mengandung sifat yang tradisional: (2) dapat berubah; dan (3) kesanggupan untuk menyesuaikan diri. Lihat: R. van Dijk, 1979, Pengantar Hukum Adat Indonesia, terjemahan A. Soehardi, Penerbit Sumur Bandung, hlm. 10.
Hukum adat berubah secaraalami mengikuti nilai-nilai yang berkembang dalam masyarakat ditandai dengan perubahan padapolakelakuan (perilaku hukum) masyarakat. Dalam kontek ini, perubahan yang terjadi dimulai dari adanya perubahan masyarakat, baru kemudian diikuti dengan perubahan hukum. Pola yang terjadi bisa sebaliknya, di mana perubahan dimulai dari adanya perubahan hukum kemudian diikuti dengan perubahan masyarakat. Secara teoritis, pola ini berkaitan dengan fungsi hukum sebagai alat perubahan sosial ("laws as a tool of social engineering”). Contoh penggunaan hukum sebagai alat untuk mengubah perilaku masyarakat antara lain dilakukan dengan memberlakukan Undang-undang Perkawinan Tahun 1974 yang mewajibkan setiap perkawinan dicatatkan di Kantor Catatan Sipil. Terlepas dari tingkat efektifitas nya, secara faktual ketentuan tersebut telah berhasil membuat masyarakat Bali mengikuti proses tertib administrasi yang digariskan oleh pemerintah, yaitu dengan mencatatkan perkawinannya di Kantor Catatan Sipil sehingga dapat diwujudkan adanya kepastian hukum dalam perkawinan. Dengan dilakukannya pencatatan perkawinan maka akan diperoleh suatu akta autentik (akta perkawinan) yang mampu membuktikan adanya perkawinan tersebut di kemudian hari. Dalam konteks lokal Bali, contoh digunakannyahukumsebagaialatuntuk mengubah perilaku masyarakat adalah 
dikeluarkannya Keputusan DPRD Bali Nomor 11/DPRD tanggal 12 Juli 1951 tentang "Perkawinan Campuran" yang menghapuskan larangan perkawinan antar kasta. Walaupun pada waktu itu nilai-nilai yang bersangkutan dengan kasta masih sangat kuat dianut oleh masyarakat Bali pada umumnya, tetapi Keputusan DPRD Bali tersebut dengan tegas mengklaim bahwa larangan perkawinan antar kasta tidak sesuai lagi dengan keadaan zaman, sehingga harus dihapuskan. Keputusan ini dapat dicatat dalam sejarah sebagai salah satu keputusan lembaga legislatif Bali yang sangat visioner dan berani ${ }^{15}$.

Contoh terbaru dari rekayasa sosialuntuk mengubah nilai-nilai, sikap dan perilaku masyarakat terkait dengan kedudukan perempuan dilakukan oleh Majelis Utama Desa Pakraman (MUDP). Sebagai pemegang otoritas adat dan hukum adat di Bali, MUDP Bali berusaha mengubah tatanan hukum adat Bali berkaitan dengan hak waris perempuan Bali. Melalui sebuah Pasamuan Agung tanggal 15 Oktober 2010 yang dihadiri oleh otoritas adat masing-masing kabupaten/kota seBali (perwakilan Majelis Madya Desa Pakraman Kabupaten/Kota dan Majelis Desa Pakraman Kecamatan), MUDP Bali mengambil keputusan, yang antara lain poin-poinnya sebagai berikut:

15 Jiwa Atmaja, 2008, Bias Gender Perkawinan Terlarang Pada Masyarakat Bali, Udayana University Press-CV Bali Media Adhikarsa, Denpasar-Bali, hlm. 147.
(1) Suami dan istrinya serta saudara laki-laki suami dan istrinya, mempunyai kedudukan yang sama dalam usaha untuk menjamin bahwa harta pusaka dapat diteruskan kepada anak dan cucunya untuk memelihara atau melestarikan warisan immateriil.

(2) Selama dalam perkawinan, suami dan istrinya mempunyai kedudukan yang sama terhadap harta gunakaya-nya (harta yang diperoleh selama dalam status perkawinan).

(3) Anak kandung (laki-laki atau perempuan) serta anak angkat (laki-laki atau perempuan) yang belum kawin, pada dasarnya mempunyai kedudukan yang sama terhadap harta gunakaya orangtuanya.

(4) Anak kandung (laki-laki atau perempuan) serta anak angkat (laki-laki atau perempuan) berhak atas harta gunakaya orangtuanya, sesudah dikurangi sepertiga sebagai duwe tengah (harta bersama), yang dikuasai (bukan dimiliki) oleh anak yang nguwubang (melanjutkan swadharma atau tanggung jawab) orangtuanya.

(5) Anak yang berstatus kapurusa berhak atas satu bagian dari harta warisan, sedangkan yang berstatus pradana/ninggal kedaton terbatas berhak atas sebagian atau setengah dari harta warisan yang diterima oleh 
seorang anak yang berstatus kapurusa;

(6) Dalam hal pembagian warisan, anak yang masih dalam kandungan mempunyai hak yang sama dengan anak yang sudah lahir, sepanjang dia dilahirkan hidup.

(7) Anak yang ninggal kadaton penuh tidak berhak atas harta warisan, tetapi dapat diberikan bekal (jiwa dana) oleh orangtuanya dari harta gunakaya tanpa merugikan ahli waris ${ }^{16}$

Putusan Pasamuan Agung MUDP di atas dapat dikatakan sebagai suatu rekayasa sosial yang visioner dan berani dilihat dari perspektif gender, terutama dalam mewujudkan kesetaraan dan keadilan gender dibidang pewarisan. Seperti diketahui, hukum adat waris yang selama ini berlaku bagi masyarakat Bali masih berpedoman kepada Paswara Tahun 1900 yang samasekali tidak memberikan hak apa-apa atas harta orang tua kepada anak perempuan yang telah kawin ke luar ${ }^{17}$. Seperti diketahui, hukum adat Bali di bidang pewarisan

16 Butir-butir keputusan tersebut tercantum pada Bagian III. Angka I Lampiran Keputusan Majelis Utama Desa Pakraman (MDP) Bali Nomor: 01/Kep/Psm-3/MDP Bali/X/2010 tentang Hasil-hasil Pasamuhan Agung III MDP Bali, tertanggal 15 Oktober 2010. Lihat: I Ketut Sumarta (Penyunting), 2010, Himpunan Hasil-hasil Pasamuan Agung III Majelis Desa Pakraman Bali, Majelis Utama Desa Pakraman (MDP) Bali, Denpasar, h. 43.

17 Lihat Peraturan (Peswara) Tanggal 13 Oktober 1900 dalam VE Korn, 1972, Hukum Adat Waris di Bali (Het Adatrecht van Bali$B a b(X)$, terjemahan I Gde Wajan Pangkat, Fakultas Hukum \& Pengetahuan Masyarakat Universitas Udayana, hlm. 62. dilandasi oleh asas keseimbangan antara tanggungjawab/kewajiban (swadharma) dan hak (swadikara). Dalam masyarakat Bali, orang yang meninggalkan tanggungjawab/ kewajiban (swadharma) dalam keluarga disebut ninggal kedaton. Pada masa lalu, anak perempuan yang sudah kawin ke luar tidak memungkinkan lagi melaksanakan kewajiban-kewajibannya di keluarga asalnya sehingga tidak berhak lagi atas harta warisan orang tuanya. MUDP melihat terjadinya perkembangan dalam masyarakat Bali dewasa ini di mana anak perempuan yang sudah kawin ke luar, dalam batasbatas tertentu masih memungkinkan melaksanakan kewajiban-kewajiban di rumah orang tuanya (disebut ninggal kedaton terbatas). Itu sebabnya MUDP berpendapat bahwa anak perempuan yang masih melaksanakan tanggungjawab di rumah orang tuanya itu dimungkinkan pula tetap mendapatkan hak atas harta warisan orang tuanya ${ }^{18}$.

Perubahan sikap terhadap hukum adat Bali menyangkut kedudukan perempuan Bali seperti yang diputuskan oleh Pasamuan MUDP Bali di atas tidak lepas dari perubahan ideologi gender dikalangan intelektual Bali, baik di lingkungan tokoh-tokoh adat di dalam MDP Bali yang hadir sebagai peserta Pasamuan maupun tokoh-tokoh gerakan perempuan dari berbagai kalangan, seperti dari

18 I Ketut Sumarta, op.cit., hlm.42. 
Lembaga Swadaya Masyarakat (LSM), akademisi, dan birokrasi, yang hadir dalam Pasamuan tersebut sebagai peninjau. Penulis yang pada Pasamuan tersebut berperan sebagai unsur pimpinan (sekretaris) Sidang Komisi Bidang Hukum Adat, ingat betul bagaimana para peninjau dari kalangan gerakan perempuan sangat gencar memberikan tekanan kepada peserta Pasamuan agar gagasangagasan mengenai perubahan hakhak perempuan Bali dalam hukum adat di akomodasi menjadi keputusan Pasamuan Agung III MUDP ${ }^{19}$. Mereka dengan setia mengikuti jalannya Pasamuan dari awal sampai akhir tanpa pernah bergeser dari tempat duduknya.

Sesungguhnya, gagasangagasan tentang perubahan kedudukan perempuan dalam hukum adat Bali sudah lama diperdengarkan, jauh sebelum Pasamuan Agung III MUDP, bahkan jauh sebelum MUDP terbentuk. Tahun 1971, dalam Diskusi Hukum Adat Waris di Bali, yang diselenggarakan di Denpasar atas prakarsa Lembaga Pembinaan Hukum Nasional (LPHN)-Projek Research Hukum Waris, telah dikemukakan pandangan-pandangan mengenai perlunya hukum waris dimodernisir sehingga dapat memberikan hak waris kepada perempuan dengan tetap memperhatikan norma-norma

19 Menurut Tata Tertib Pasamuan, peninjau diberikan hak bicara, tetapi tidak mempunyai hak suara dalam pengambilan keputusan. agama $^{20}$. Sayang sekali pemikiranpemikiran visioner yang muncul dalam berbagai diskusi tetap tinggal sebagai gagasan yang tidak pernah diwujudkan dalam produk hukum apapun. Putusan-putusan Pengadilan mengenai sengketa waris setelah itu pun tetap menempatkan perempuan pada posisi yang sangat lemah dalam pewarisan, terutama bagi anak perempuan yang sudah kawin ke luar. Hukum adat Bali tetap menempatkan perempuan sebagai ahli waris terbatas dan bersyarat. "Ahli waris terbatas" dalam arti kedudukannya hanya berhak menikmati harta warisan, bukan "memiliki" sehingga tidak dapat dengan bebas memanfaatkan harta tersebut sebagai milik, seperti: memindahtangankan, menjual, menggadaikan, dan sebagainya sesuai keinginannya. "Ahli waris bersyarat", maksudnya bahwa haknya itu (hak menikmati hasil) hanya berlaku dengan syarat atau selama perempuan itu tidak kawin ke luar ${ }^{21}$. Dengan demikian, adanya Keputusan Pasamuan Agung MUDP Bali tahun 2010 di atas dapat dipandang sebagai tonggak penting bagi perubahan hak-hak perempuan Bali dalam hukum adat Bali, terutama dalam bidang pewarisan.

20 Lihat hasil-hasil diskusi Hukum Adat Waris di Bali, dalam V.E. Korn, op.cit, hlm. 48.

21 A.A. Oka Mahendra, at. all., 1996, "Laporan Akhir Penelitian Tentang Perkembangan Hukum Waris Janda dan Anak Perempuan dalam Masyarakat Bali”, Kerjasama Antara Fakultas Hukum Universitas Udayana dan Badan Pembinaan Hukum Nasional Departemen Kehakiman RI, hlm,. 57. 
Walau diakui bahwa keputusankeputusan Pasamuan Agung tersebut tidaklah serta merta akan diikuti dan dijadikan pola kelakuan yang ajeg sebagai hukum adat dalam kenyataan oleh masyarakat Bali saat ini, tetapi keputusan tersebut akan berpengaruh bagi perkembangan hukum adat Bali di masa depan. Pertama, keputusan MUDP itu akan menjadi pedoman dalam revitalisasi hukum adat Bali melalui penulisan awig-awig desa pakraman, karena salah satu fungsi MUDP adalah melakukan pembinanan terhadap awig-awig desa pakraman. Dengan begitu, akan terjadi sosialisasi daninternalisasidikalanganmasyarakat hukum adat Bali mengenai nilai-nilai yang terkandung dalam Keputusan MUDP tersebut sehingga diharapkan membawa pengaruh yang signifikan bagi kemajuan hak-hak perempuan Bali di dalam pewarisan. Kedua, keputusan Pasamuan Agung MUDP tersebut berikut hasil sosialisasinya berupa produk hukum adat dalam bentuk awig-awig, akan memudahkan bagi hakim untuk melakukan penemuan hukum adat (rechtsvinding) dalam tugasnya menggali nilai-nilai hukum yang hidup dalam masyarakat, ketika hakim di Pengadilan-pengadilan yang ada di Bali mengadili kasus-kasus pewarisan. Dengan demikian, hakim dalam memberikan putusan tentang sengketa warisan menyangkut hak perempuan dalam mewaris diharapkan akan mengikuti asas-asas hukum yang menjadi substansi putusan MUDP tersebut.

\section{KESIMPULAN}

Akhirnya, sebagai simpulan dapat ditegaskan kembali pokokpokok pikiran dari uraian di atas. Pertama, ideologi gender adalah seperangkat ide-ide dan sistem nilai yang meligitimasi persifatan, peran dan status laki-laki dan perempuan. Ideologi gender menyangkut segala nilai, norma, pelabelan yang berkaitan dengan relasi antara perempuan dan laki-laki yang didahului pembentukan identitas feminin dan maskulin yang menjadi struktur dan sifat manusia yang dibentuk sejak masa kanakkanak. Dalam ranah hukum, nilainilai yang hidup dalam masyarakat melandasi pembentukan normanorma hukum yang berlaku di dalam masyarakat yang bersangkutan, baik yang berupa hukum tertulis (umumnya berupa hukum negara) maupun tidak tertulis (umumnya berupa hukum adat). Dengan demikian, apabila terjadi perubahan pada tataran nilai maka akan menyebabkan terjadinya perubahan pada norma-norma hukumnya. Demikianlah yang terjadi pada nilai-nilai yang menyangkut relasi antara laki-laki dan perempuan dalam masyarakat adat Bali, perubahan nilai-nilai gender merupakan suatu keniscayaan. Intensitas perubahannya mungkin lambat dan pada kalangan masyarakat yang juga terbatas, tetapi disadari atau tidak, saat ini telah terjadi perubahan ideologi (nilai-nilai) gender dalam masyarakat adat Bali yang mengarah kepada kesetaraan dan keadilan gender. 
Perubahan ideologi gender dalam masyarakat adat Bali, terutama yang terjadi dikalangan intelektual dan tokoh-tokoh adat, menyebabkan lahirnya Keputusan Pasamuan Agung III Majelis Utama Desa Pakraman (MUDP) Bali Tahun 2010 yang secara tekstual mengangkat derajat dan harkat perempuan Bali di bidang pewarisan, di mana diputuskan bahwa perempuan dalam batas-batas tertentu berhak atas harta peninggalan orang tuanya. Dilihat dari perspektif gender, keputusan tersebut cukup progresif dan visioner karena akan berpengaruh terhadap hukum adat Bali di bidang pewarisan di masa depan yang mengarah kepada hukum adat waris yang berkeadilan gender. Seberapa besar pengaruhnya dan seberapa cepat hal itu terjadi sangat tergantung dari efektifitas sosialisasi Keputusan Pasamuan Agung MUDP tersebut kepada masyarakat.

Untuk mempercepat terwujudnya hukum adat waris Bali yang berkeadilan gender, maka sangat penting digencarkan pelaksanaan sosialisasi Keputusan-keputusan Pasamuan Agung III MUDP tersebut, khususnya yang menyangkut kedudukan perempuan Bali, tidak hanya di kalangan para pengambil kebijakan dan praktisi hukum (hakim, jaksa, kepolisian), tokoh adat dan agama, tetapi juga dikalangan masyarakat adat. Dengan banyaknya sosialisasi, diharapkan Keputusan MUDP benar-benar dapat berfungsi sebagai rekayasa sosial menuju hukum adat Bali yang berkeadilan gender dan dapat diterima dan dilaksanakan oleh masyarakat luas.

\section{DAFTAR PUSTAKA}

Agnes Widanti, 2005, Hukum Berkeadilan Gender, Penerbit Buku Kompas.

Bambang Sunggono, 2003, Metodologi Penelitian Hukum, PT RajaGrafindo Persada, Jakarta.

Dijk, R. van 1979, Pengantar Hukum Adat Indonesia, terjemahan A. Soehardi, Penerbit Sumur Bandung.

Fakih, Mansour 1996, Analisis Gender \& Transformasi Sosial, Pustaka Pelajar, Yogyakarta.

Inayah Rohmaniyah , 2009, ”Gender dan Konstruksi Perempuan dalam Agama", Jurnal Studi Ilmu-ilmu Al Quran dan Hadis, Vol 10 No 2, Juli 2009

Jiwa Atmaja, 2008, Bias Gender Perkawinan Terlarang Pada Masyarakat Bali, Udayana University Press-CV Bali Media Adhikarsa, Denpasar-Bali.

Kelompok Kerja Convention Watch Pusat Kajian Wanita dan Gender Universitas Indonesia, 2004, Hak Azasi Perempuan, Instrumen Hukum untuk Mewujudkan Keadilan Gender, Yayasan Obor, Jakarta.

Korn, V.E., 1972, Hukum Adat Waris di bali (Het Adatrecht van BaliBab IX), Diterjemahkan serta diberi catatan-cataatn oleh I Gde Wajan Pangkat. 
Lauer, Robert H., 2001, Perspektif tentang Perubahan Sosial, terjemahan Alimandan, PT Rineka Cipta, Jakarta.

Mahendra, A.A. Oka at. all., 1996, "Laporan Akhir Penelitian Tentang Perkembangan Hukum Waris Janda dan Anak Perempuan dalam Masyarakat Bali”, Kerjasama Antara Fakultas Hukum Universitas Udayana dan Badan Pembinaan Hukum Nasional Departemen Kehakiman RI.

Pusat Bahasa Departemen Pendidikan Nasional, 2001, Kamus Besar Bahasa Indonesia, Edisi Ketiga, Balai Pustaka, Jakarta.

Siti Cholisotul Hamidah , 2014, "Representasi Ideologi Gender dalam buku Teks Bahasa Indonesia", tersedia di http://karya-ilmiah.um.ac. id/index.php/disertasi/article/ views/37015, diakses: 22 Januari 2017.

Sumarta I Ketut (Penyunting), 2010, Himpunan Hasil-hasil Pasamuan Agung III Majelis Desa Pakraman Bali, Majelis Utama Desa Pakraman (MDP) Bali, Denpasar.

Windia, Wayan P dan I Ketut Sudantra, 2006, Pengantar Hukum Adat Bali, Lembaga Dokumentasi dan Publikasi Fakultas Hukum Universitas Udayana. 